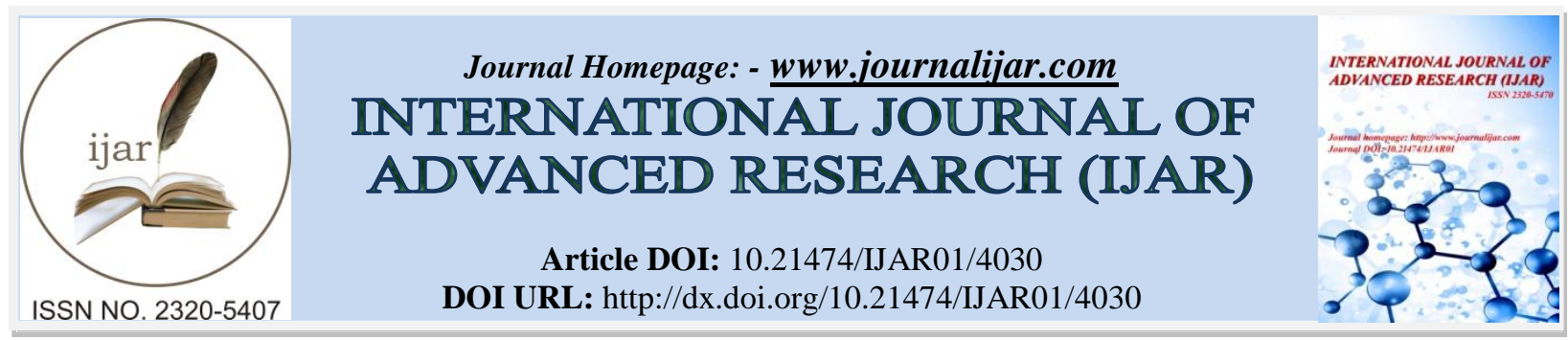

RESEARCH ARTICLE

\title{
THE CONSEQUENCES OF APPLIED SOME PUNITIVE SYSTEMS AND THEIR ROLE IN CRIMINAL REHABILITATION.
}

Dr. Khalied Mohammad Ajaj.

Department of Law, College of Law, Cihan University, Sulaimanya.

\section{Manuscript Info}

Manuscript History

Received: 26 February 2017

Final Accepted:21 March 2017

Published: April 2017

\section{Abstract}

The punitive treatment is not limited to punitive institutions, but can be carried out outside these institutions in the free environment, without any part of it being implemented within the punitive institutions or part of it is implemented in punitive institutions,subject to some of the obligations that must be fulfilled by the convicted person until proven such treatment under certain conditions. The most important of these systems are the suspension system, the police release system and the judicial testing system.

Copy Right, IJAR, 2017,. All rights reserved.

\section{First: The Suspension System}

Execute the suspension on a group of criminals, whose situation and circumstances lead them to believe that they will not return to criminality again,such as criminals of passion and criminals by accident, the application of thesuspension regime to this category of criminals, including many benefits, including reform and rehabilitation. As well as to prevent those sentenced to the risk of infection from dangerous criminals inside the prison [1].

First: Definition of Suspension: The suspension is defined as suspending the execution of the penalty on a standing condition within a specified period specified by law. This standing condition is the perpetrator's offense during the period of suspension [2] [3].

The suspension of implementation contradicts the two concepts of the French concept, namely, the verdict of conviction and then the suspension of a certain period during which the convict is left without any obligation unless he commits a new crime leading to the cancellation of the suspension [4] [5].

The situation of the sentenced person who received a retrial is considered to be the removal of the ruling from the previous crime page. As a result, he is not considered a return if he commits a new crime. Most of the legislation in Europe was adopted by the Egyptian and Iraqi legislators. [6]. The other concept, which is the German concept goes to the former judicial judgment, considering this provision and did not implement a precedent in the previous crime in the sense that the conviction remains in place unless the sentenced to a judgment is considered.

Second:Conditions of Suspension:

A. Conditions related to the sentenced: Art. 144 of the Iraqi Penal Code requires the suspension of execution that the offender has already been sentenced to a deliberate crime regardless of the causes, whether a felony or a misdemeanor or a violation and provided the date of the crime and also require the court to see the ethics of the 
sentenced The past, the age and the circumstances of his crime make it believable that he will not return to committing a new crime.

B. Conditions related to the penalty:-

1. Punishment shall be punishable by penalties for deprivation of liberty, although some legislation goes to suspend the implementation of the fine [7].

2. The term of the sentence to be suspended shall not exceed one year. This is what has been adopted by most legislation, including Iraqi-Egyptian legislation.

\section{Conditions related to the crime:-}

It is required that the crime be a crime and misdemeanors, either irregularity may not be stopped[8].

Third: Evaluation of the suspension system: [6]

The system of suspension is subject to many criticisms, the most important of which are:

1. This system does not achieve the rehabilitation and refinement that requires that the subject be sentenced to him because he is not subject to rehabilitation and reform programs.

2. This system is not consistent with modern penal policy as the sentenced remains throughout the trial period without guidance and supervision.

3. This system does not include obligations imposed on the sentenced to ensure his good conduct during the trial period.

\section{Pros of application:-}

Despite the criticisms against the suspension regime, the system has many advantages, including the avoidance of the disadvantages of implementing short-term sanctions against the sentenced person, which is often less dangerous to criminals than dangerous, and the inevitable result is to leave prison after the expiration of the sentence More dangerous before entering prison [9]. In other words, the system of suspension means that criminals who are dangerous and experienced in crimes are not mixed with novice or non-dangerous offenders. This system also gives the convicted person an opportunity to reform himself away from prisons, so this system is considered a reform system that is preferred to keep it.

\section{Second: judicial examination:-}

First: Definition and image of the judicial test: It means restricting the freedom of the sentenced person before and after his sentence, instead of depriving his freedom as a means of reforming him [10].

The judicial test according to this definition has a negative and positive concept negative concept leads to avoid the sentenced to implement the penalty within the penal institution to prevent that damage mixing. The positive concept is meant to supervise him and to help him to walk in a honorable way of life with the imposition of judicial control over him. If this system succeeds in reforming him, he will avoid executing the punishment against him. If he fails, he will be returned to the penal institution to rehabilitate him.

\section{Judicial test photos:-}

The judge's opinion is that the accused is entitled to a conviction, but the judge finds that it is more appropriate for the accused not to pronounce the sentence and subject the accused to a trial period in which the judge determines who is interested. If he fails to do so, the penalty shall not be imposed within the penal institution [11].

One advantage of this picture is that the accused does not know the amount of punishment that will be imposed on him, making him more committed to the duties imposed on him. It also allows the judge to examine the case of the accused more during the probationary period for sentencing.

The second is the test after the verdict of conviction: It is intended to suspend the execution of the sentence after it was issued within a specified period of time and put the offender under social supervision and supervision of the judiciary subject to the requirements of guidance appropriate to his condition and social circumstances [12].

If he passes the test successfully, the sentence of conviction is dropped by the force of the law and he prepares as if it was not. If he fails to pass the test, the penalty against him shall be imposed against him [11]. 
One of the advantages of this picture is the speed of the verdict of convicting the accused once convicted and that the accused is threatened to carry out the punishment if his behavior is misbehavior and breached his obligations [13].

Third: Judicial Test Conditions:-

A - The conditions of the accused: The judicial test applies only to those offenders who reveal the social and medical examination applied to them as they can be integrated into society outside the prison walls to achieve their reform and rehabilitation [6].

B - Conditions related to the crime assigned to the accused: Criminal legislation differed on the issue of conditions related to crime British legislation tends to exclude this system from the perpetrators of serious crimes, which are punishable by death or life imprisonment. The law exempts the regime from crimes of violence against the government or those committed for public money. French legislation excluded crimes with a maximum sentence of more than five years, and ruled out its application to political criminals and those who had previously failed to test [6] [14].

\section{Third requirement:-}

\section{System of conditional release:-}

First: Definition of conditional release:-

The conditional release is defined as the release of the convict with a deprivation of liberty before the expiry of his sentence, provided that he is committed to maintaining his good conduct during the remaining period of his sentence. If he does not comply [15].

It is clear from this definition that the system of police release is scheduled for a group of those sentenced to a deprivation of liberty who have shown willingness to reform themselves according to the programs allocated to them in that system [16].

\section{Conditional release conditions:-}

\section{A. Conditaions related to the sentenced person [17]:-}

1- The convicted person shall have good conduct during his presence in the penal institution.

2. The convicted person has fulfilled all his financial obligations which the court has charged him as fines and compensation to the victim.

\section{B- Conditions related to punishment [17] [18]:-}

1. The convicted person may have spent three-quarters of his sentence if he is an adult or two-thirds of the sentence if he is an juvenile within the penal institution. This period is agreed upon by all Arab laws, including Iraqi law, as in Article 331 of the Code of Criminal Procedure.

2. The period spent by the convicted person within the penal institution shall not be less than six months.

\section{The position of the Iraqi legislator of the conditional release:-}

Iraqi law dealt with the provisions on conditional release in the Code of Criminal Procedure in Articles 330-370. Which stipulates that the convict must spend three quarters of the sentence within the penal institution in order to be released after the other conditions have been met? As for the release of the person sentenced to life imprisonment, he must be completed at least fifteen years of his sentence.It is worth mentioning that the Iraqi legislator. However, the Iraqi legislator adopted a system of suspension and the system of police release, but he did not take the judicial test system. We call upon him to take this system because of his role in reforming the sentenced person, especially as he applies with finding practical solutions to the convicted. Monitor his behavior.

\section{References:-}

1. Dr.AliRashed, "The Brief in Criminology Law", Vol3, The Arabic Book Press, Egypt, 1955, PP651.

2. Dr.MohammedAlfazel, "General Principles in Criminology Law", Vol 3, Syria, 1964, PP 660.

3. Dr.RaofObaid, Principles of criminology constitution" vol 3, Arabic Home of Thinking, Egypt, 1966, PP581.

4. Dr. Omer Mohammed Salem, "new seen in the suspension execution in the criminology Law", Vol 1, Arabic revolution Press, Egypt, 1998, PP96.

5. Dr.Husain Ibrahim, "Lectures in Crimes", Vol 1, Arabic revolution Press, Egypt, 1998, PP 76.

6. Dr.Ammar Abas Alhussaini, " Crimes Ablications", PP408.

7. Dr. Mahmood NajeebHasany, "Explanation of Criminology Law" General Section, Vol.4, Arabic Evolution home, Egypt, 1977, PP.837. 
8. Dr. HameedeAlsady, "Explanation of Novel Criminology Law", Vol.1, Knowledge Press, Baghdad, 1970, PP377.

9. Dr. AbdulMoatiAbdulkhalik, "Principles of criminology:, Arabic Evolution home, Egypt, PP 306.

10. Dr.FawziaAbdulSatar, "Principles of Criminology and Penalty", PP 414.

11. Dr.TarikhAbdulwahabSaleem, "The introduction to Criminology", Arabic Home Revolution Press, Egypt, PP487.

12. Nidhal Yassin HamoAlEbadi, "Judgment Test", Dar Shatat Press, Egypt, 2012, PP 2.

13. Dr.Ihabyeser Anwar, "Judgment Test", Dar AlnahzaAlarabiya" Egypt, 2000, PP 24.

14. Dr. Mohammed Muhammed MusbahAlkazi, " Criminology", PP 218.

15. Dr.AkramNashat Ibrahim, "General Judgments in Iraqi Crime Law", Asaad Press, Baghdad, 1962, PP 148.

16. Dr. WathibahAlsaady, "Conditional released System", Lectures Notes, Law Faculty, Baghdad University, 1988, PP 4.

17. Dr.AliAbdulkadirAlkahwaji, "Originality of Criminology", PP 238.

18. Dr.MohammedMAarof, " Criminology", PP122. 